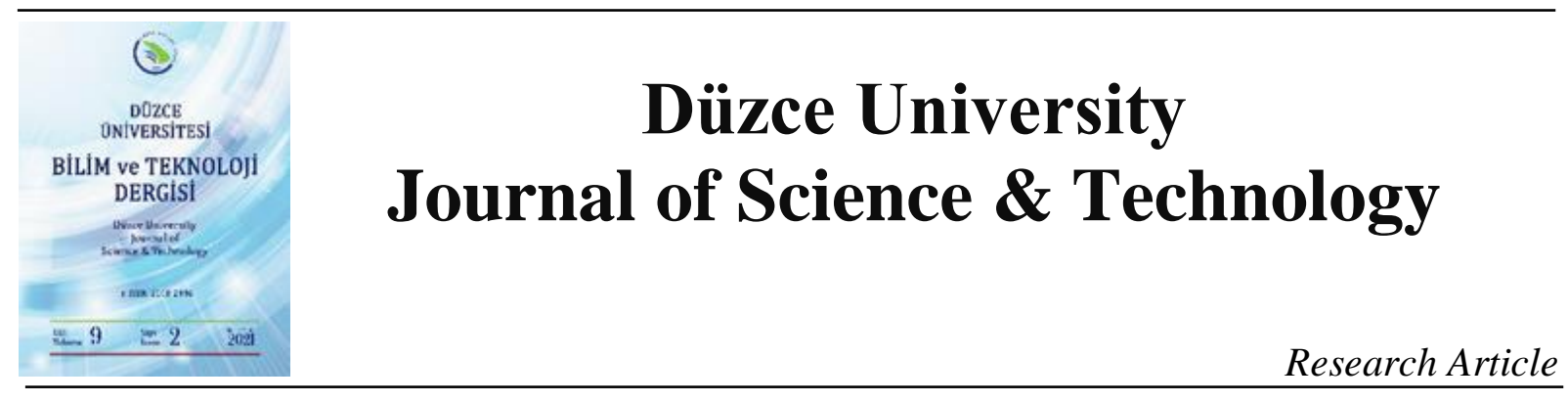

\title{
Influence of Particle Size on the Structure and Properties of 316L Hollow Fiber Membranes Sintered Under Argon Atmosphere
}

\author{
Ezgi ŞAHIN ${ }^{a, b}$, (D) Onur ERTUĞRUL ${ }^{a}{ }^{*}$, (D) Özgün YÜCEL ${ }^{c}$ \\ ${ }^{a}$ Materials Science and Engineering Department, Engineering and Architecture Faculty, İzmir Katip Çelebi \\ University, İmir, TURKEY \\ ${ }^{b}$ TÜBITAK Informatics and Information Security Research Center (Bilgem), Kocaeli, TURKEY \\ ${ }^{c}$ Chemical Engineering Department, Engineering Faculty, Gebze Technical University, Kocaeli, TURKEY \\ * Corresponding author's e-mail address: onur.ertugrul@ikcu.edu.tr
}

DOI: 10.29130/dubited.868915

\begin{abstract}
316L based stainless steel hollow fiber membranes (HFs) are used as an alternative for polymer and ceramic based membranes. Areas where $316 \mathrm{~L}$ hollow fiber membranes used are applications such as supports or particle filters of gas and liquid separations in chemical and waste treatment industries. Among various methods, dry-wet spinning technique was selected as the production method of hollow fiber membranes since it is the most popular one. The aim of the study is to produce hollow fiber membranes in different powder particle sizes (coarse, fine, and their mixture), and to examine their structure and also their properties such as chemical compositions, pore amount, average pore size, and pore distribution. 3-point bending tests were also used to determine their mechanical properties. HFs produced from fine particles show higher densification than coarse particle size samples. In terms of pore structure, mixed particle size yields lower porosity and pore size than the finest particle size. On the other hand, the finest particle size yields the highest bending strength and bending deflection.
\end{abstract}

Keywords: Hollow fiber, Membrane, Dry-wet spinning, 316L, Sintering

\section{Partikül Boyutunun Argon Atmosferi Altında Sinterlenen 316L İçi Boş Fiber Membranların Yapısına ve Özelliklerine Tane Etkisi}

\begin{abstract}
ÖZET
316L paslanmaz çelikler içi boş fiber membranlar, polimer ve seramik esaslı membranlara alternatif olarak kullanılmaktadır. 316L içi boş fiber membranların kullanım alanları kimya ve atık arıtma endüstrilerinde gaz ve sıvı ayrıştırmaları için destek ve partikül filtreleri gibi uygulamalardır. Birçok metod arasında, üretim tekniği olarak en popüler olan kuru-1slak eğirme tekniği seçilmiştir. Çalışmanın amacı farklı toz partikül boyutlarında (kaba, ince ve bunların karışımı) içi boş fiber membranların üretilmesi ve bunların yapıları ve kimyasal kompozisyon, gözenek miktarı, ortalama gözenek boyutu ve gözenek dağılımlarını incelemektir. Aynı zamanda, mekanik özellikleri belirlemek amacıyla 3-nokta eğme testleri uygulanmıştır. İnce partiküllerden üretilen numuneler kaba partikül boyutlu numunelerden daha yüksek yoğunlaşma göstermektedir. Gözenek yapısına bakıldığında, karışım partikül boyutu ince partikül boyutuna kıyasla daha düşük gözeneklilik ve gözenek boyutu sunmaktadır. Öte yandan, en küçük partikül boyutu en yüksek mukavemet ve eğilme miktarı sunmaktadır.
\end{abstract}

Keywords: İçi Boş Fiber, Membran, Kuru-Islak Eğirme, 316L, Sinterleme 


\section{INTRODUCTION}

Membrane technologies and membrane materials are mainly used in applications such as gas separation and water treatment. Membranes can be produced from several materials classes such as ceramics, polymers and nowadays metals [1]. Hollow fiber (HF) membranes are used because they have improved surface area/volume, lower capital costs, lowest sealing perimeter, and capability of backwashing [2]. They are used in gas separations, water treatments, and in the medical areas for blood filtration [3].

Ceramic based hollow fiber membranes have drawbacks of high brittleness and low strength for industrial applications [4-6]. In order to eliminate these problems, metallic materials have been used for HF membranes today, which could provide toughness and high mechanical strength [7]. Also, metals have well-known resistance to chemical oxidation, thermal cleaning treatments, providing reusability properties [8]. For the past ten years, there are a few reports about the production of metal based hollow fiber membranes, and the focus is on $316 \mathrm{~L}$ stainless steels due to their good strength-ductility combination. Luiten-Olieman et.al. studied one of the first reports on porous stainless steel HF membranes in 2011 [9]. HF membranes were produced by dry-wet spinning technique, which creates finger-like voids and sponge-like regions. Pore sizes in the finger-like voids can be large up to >200 micron, and sponge-like regions contain pores in the range of 3-5 micron and sometimes submicron [2]. These pores are suitable as support materials but not as membranes. As a solution, Diego R. Schmeda-Lopez et. al. used stainless steel matrix carbon containing HF's, where the binder is pyrolized in the stainless steel matrix, which fills the gaps between the SS particles and reduces the pore size [10].

Sintering step on green hollow fibers has crucial importance since all organic additives and binders should be removed in a controlled way [11]. Hydrogen, nitrogen or argon atmospheres are used to protect SS hollow fibers during the sintering process [9,12]. The sintering atmosphere affects mechanical properties and corrosion behaviours of $\mathrm{HF}$ membranes [13,14]. Also, high sintering temperature (higher than $1150{ }^{\circ} \mathrm{C}$ ) is preferred to achieve higher sintered density. Reducing the surface oxides results in increase corrosion resistance and ductility [14]. On the other hand, oxygen, carbon, nitrogen and iron contamination determine the corrosion behaviour [15]. Sintering of SS in nitrogen atmospheres results in precipitation of chromium nitride, and it results in advanced mechanical properties yet degradation of corrosion resistance [13,14]. Therefore, argon atmosphere is commonly preffered as an economical inert atmosphere [15].

Moreover, there are new studies about particle size importance in hollow fiber membranes [16]. It can be seen that small particle sizes are better in HFs. It affects extrusion performance of the mixture directly. Particle size also affects green strength, thus enhancing densification and properties of the sintered products [17]. Therefore, 316L parts with high densities present improved mechanical properties [18].

In the present study, porous 316L HF membranes have been prepared using the dry-wet spinning technique, based on phase inversion and sintering technique. The aim of the study is to produce hollow fiber membranes in different powder particle sizes under Argon sintering atmosphere, and to examine their detailed morphological and structural properties. It was aimed to investigate the particle size effect using very fine particles, coarser particles and the mixture of these two. These materials are that may be of interest for industries such as environment, chemistry and waste disposal.

\section{MATERIALS AND METHOD}

\section{A. MATERIALS AND CHEMICALS}

$3 \mu \mathrm{m}$ (fine) and $20-53 \mu \mathrm{m}$ (coarse) 316L stainless steel powders (obtained by Sigma Aldrich and Höganas-AB, respectively) are used in this study. Also, polymethylmethacrylate (PMMA), N-Methyl2-pyrrolidone (NMP), and polyvinylpyrrolidone (PVP), obtained by Sigma Aldrich, are used as 
polymeric binder, solvent and viscosity adjusting materials, respectively. The chemicals are not pretreated.

\section{B. SOLUTION PREPARATION PROCEDURE}

The solution preparation step starts with the mixing of PMMA and NMP for 12 hours. Then, $316 \mathrm{~L}$ stainless steel powders are added to the solution slowly and are mixed for 3 hours. Finally, PVP is added and all of them are mixed for 30 mins. This suspension is then placed in a vessel and then vacuum is degassed. After degassing, the spinning suspension pressure is increased with the help of the syringe pump and extrusion is performed with the help of the spinnerret. The amounts of components in the solution are given in Table 1.

Table 1. Mass values of the components in the solution

\begin{tabular}{ccccc}
\hline Components & $316 \mathrm{~L}$ & NMP & PMMA & PVP \\
\hline $\begin{array}{c}\text { Suspension composition } \\
\text { (grams) }\end{array}$ & $42 \mathrm{~g}$ & $14.4 \mathrm{~g}$ & $4.2 \mathrm{~g}$ & $0.2 \mathrm{~g}$ \\
\hline
\end{tabular}

Three different particle size distributions were used as coarse, fine and their mixture (bimodal distribution). The representative codings are shown in Table 2.

Table 2. Sample coding and particle sizes

\begin{tabular}{cc}
\hline Sample Codes & $\begin{array}{c}\text { Particle size } \\
\text { (microns) }\end{array}$ \\
\hline C-SS & $100 \%$ coarse 316 powder \\
F-SS & $100 \%$ fine 316 powder \\
M-SS & mixed (75\% fine+25\% coarse) 316L powder \\
\hline
\end{tabular}

\section{PRODUCTION PROCEDURE}

Hollow fiber membranes are produced by the dry-wet spinning process. Membrane production setup consists of solutions, syringe pumps, nozzle, internal coagulant and coagulation bath. The solution and the internal coagulant are simultaneously pumped towards the nozzle. They flow through the coagulation bath after passing through the air gap at definite distances. The extrusion step should be performed carefully in order to obtain homogeneous and continuous hollow fibers. The HF samples were kept in pure water in a bath for 1 day to remove from solvent and additives, and solidification is provided. Then, they are taken from the bath to dry for 1 more day and kept on a paper. Finally, the green samples become ready for the sintering stage.

Hollow fiber green bodies are sintered in $100 \%$ Argon atmosphere at $1150^{\circ} \mathrm{C}$ temperature for 90 mins. This complete process is called dry-wet spinning technique in the literature. Then, structural and mechanical properties for three different particle sizes were examined separately.

\section{CHARACTERIZATION STUDIES}

The effects of particle sizes were characterized to reveal the structure and shape of the HFs, to obtain chemical compositions, pore amount, average pore size and pore distributions. Scanning Electron Microscope and EDX Analysis were used to obtain cross-section views, and to reveal membrane morphology. X-Ray Diffraction Analysis were used to obtain the crystal phases of SS hollow fiber membranes by Bruker D2 Phaser device. The electrical resistance of the HFs were measured with a multimeter (Keysight, 34461A Digit Multimeter). Mercury Porosimeter Analysis were used to obtain the pore amount and pore size distribution using a Micromeritics AutoPore IV 9500 porosimeter. Threepoint bending tests were done using Shimadzu mechanical test device. Three-point bending tests were 
done by universal testing machine (Shimadzu, Japan). The strain rate was set to $1 \mathrm{~mm} / \mathrm{min}$ and the span was $20 \mathrm{~mm}$. Bending strength values were calculated using the equation below:

$\sigma f=\frac{8 F L D}{\pi\left(D^{4}-d^{4}\right)}$

where $\mathrm{F}$ is the fracture force $(\mathrm{N}), \mathrm{L}$ is the length, $\mathrm{D}$ is the outer diameter and $\mathrm{d}$ is the inner diameters of the HF samples (m). Here, samples with $26 \mathrm{~mm}$ length, $1.70 \mathrm{~mm}$ as outer diameter and $1.10 \mathrm{~mm}$ as inner diameter were used.

\section{RESULTS AND DISCUSSION}

\section{A. UNSINTERED SAMPLES}

Figure 1 represents the SEM images of the unsintered HF samples. Samples made of coarse particles have inhomogeneous cross sections, and contain very large pores in the center of the HF as seen in A13. Samples made of fine powders have homogeneous cross sections as similar with many literature studies (B1-3) [10, 19, 20]. The asymmetric structures contain sponge-like regions and finger-like voids as shown in $\mathrm{B} 2$ and $\mathrm{C} 2$.
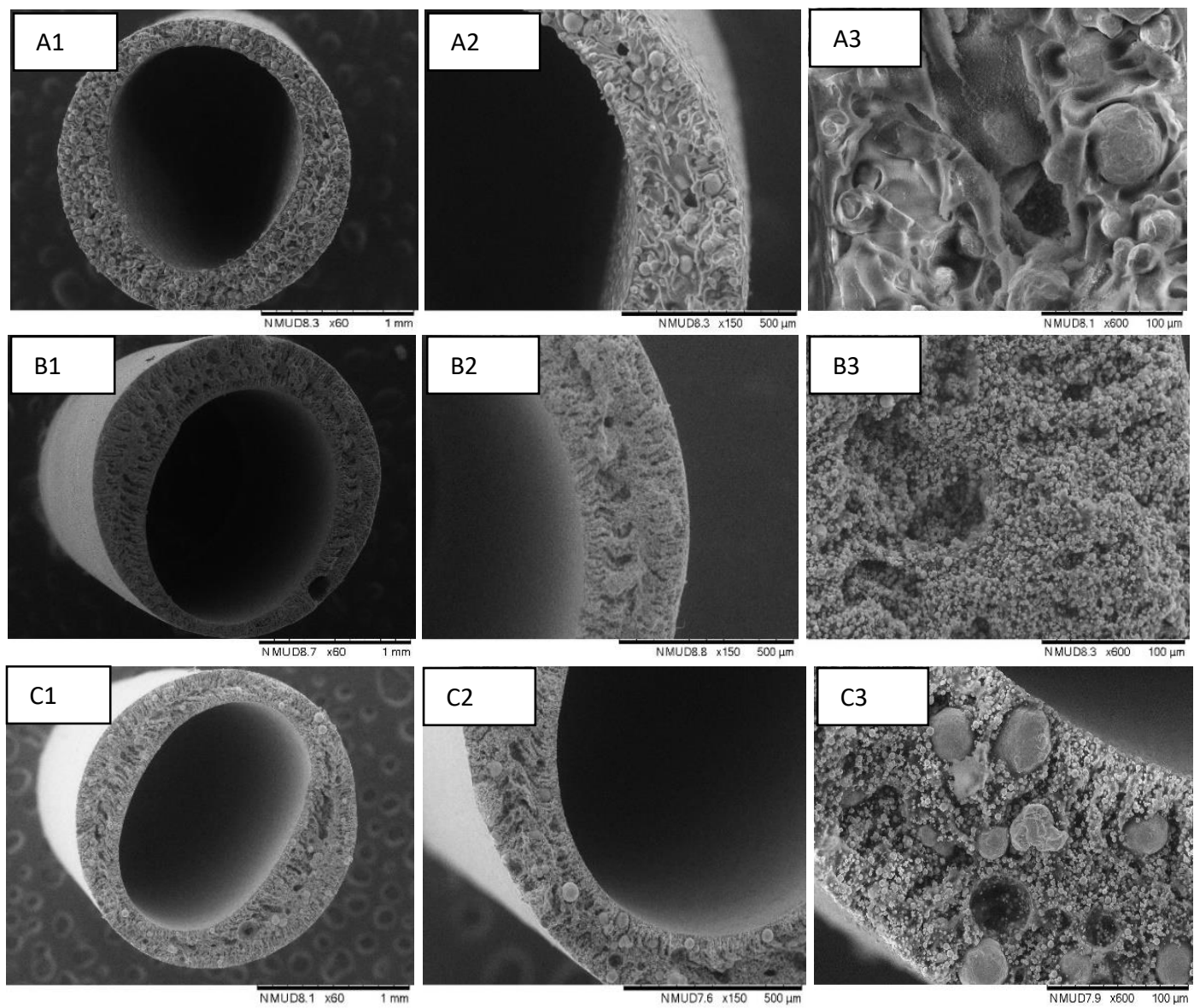

Figure 1. Three different magnificant belong to unsintered samples A1-3) C-SS, B1-3) F-SS, C1-3) M-SS. 


\section{B. SINTERED 316L SAMPLES}

\section{B. 1. Structures of Hollow Fibers}

Figure 2 shows the SEM images of cross-sections of the three different argon atmosphere sintered samples in order to evaluate the morphology of the fibers. Both spinning and sintering processes were performed successfully as sintered HF samples have homogenous hollow structure and shape. Sintering was carried out in argon atmosphere. It seems that all polymeric binder has been pyrolyzed from the HF structure successfully.

When particle sizes are compared, membrane with finest particles has higher densification in terms of microstructure, also have a dominant finger-like structure but also some sponge-like structures. These two structures are typical which are the required signs from hollow fibers. The finger-like structure occurs from inner surface, the sponge-like structures are located at the outer region of the cross-section [20]. The finger-like voids were formed due to fast exchange between solvent (NMP) and no-solvent (water) while sponge-like structure was formed due to slow exchange during the spinning process [17].

Sponge like structures and finger like voids become dominant for the fine particle size HFs (F-SS). The finger-like structures are observed in B1 while sponge-like structures are observed for $\mathrm{C} 1$. For the samples with coarse particles A1-A2, large pores are obtained. Therefore, finger-like voids and sponge like structures are not obtained in these samples. These results are consistent with the literature studies which showed that smaller particles yield finger-like structures $[10,20]$ and because of this reason, 316L particle size around 3-10 microns is preferred [3,10,19].

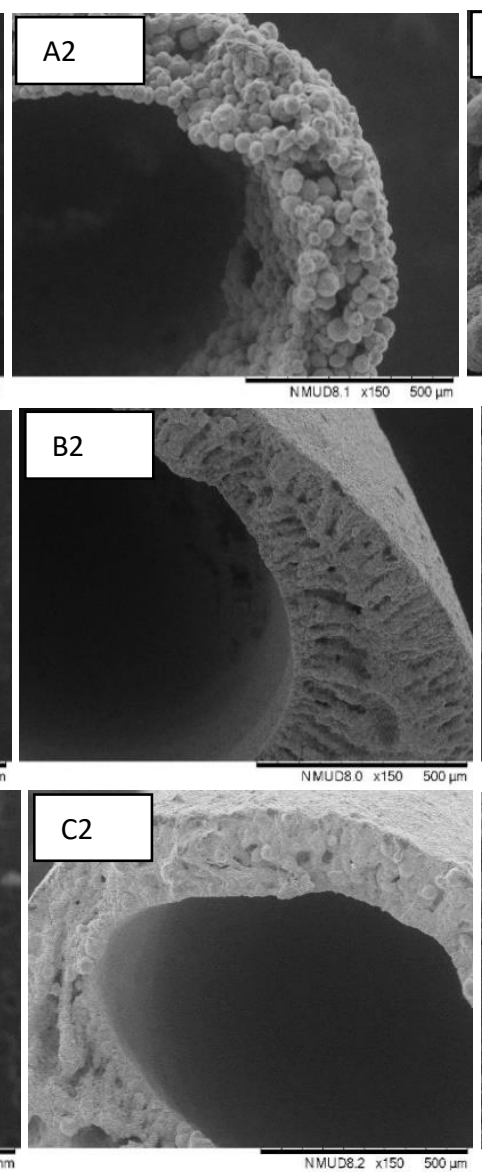
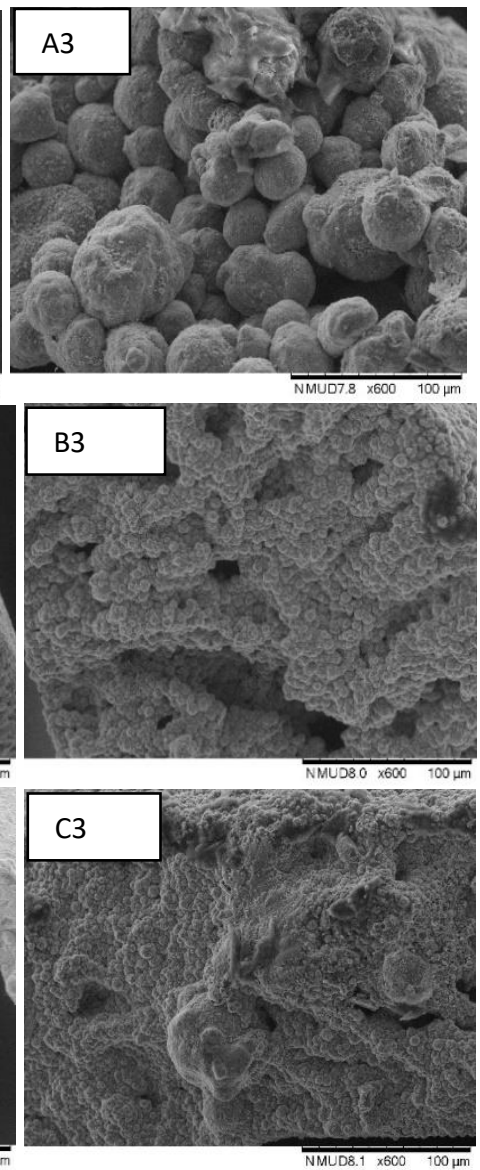

Figure 2. SEM images belong to sintered samples A1-3) C-SS, B1-3) F-SS, C1-3) M-SS. 
Table 3 shows the EDX analysis of the three different compositions of Ar sintered HF membranes. Both compositions contain the major components of SS such as $\mathrm{Fe}, \mathrm{Cr}, \mathrm{Ni}$, Mo. Table 4 shows the densificationn behaviour of SS HF membranes by showing the densification values. As a result, mixed particle size composition yields higher densification which can be attributed to more efficient sintering than the other two.

Table 3. Elemental compositions (wt\%) from the EDX analysis of sintered HF samples

\begin{tabular}{llllllllc}
\hline Sample codes & \multicolumn{8}{c}{$\begin{array}{c}\text { Elemental composition } \\
(w t \%)\end{array}$} \\
\cline { 2 - 10 } & Fe & $\mathbf{C r}$ & Ni & Mo & O & Si & N & C \\
\hline C-SS & 36 & 54 & 2 & 1 & 7 & - & - & - \\
F-SS & 79 & 9 & 1 & 1 & 10 & - & - & - \\
M-SS & 60 & 24 & 8 & 2 & 6 & - & - & - \\
\hline
\end{tabular}

Table 4. Densification of sintered hollow fiber membranes.

\begin{tabular}{cc}
\hline Sample codes & $\begin{array}{c}\text { Shrinkage } \\
(\%)\end{array}$ \\
\hline C-SS & 49.2 \\
F-SS & 55.2 \\
M-SS & 67.4 \\
\hline
\end{tabular}

\section{B. 2. X-Ray Diffraction (Xrd) Analysis}

XRD analysis was performed to $316 \mathrm{~L} \mathrm{HF}$ samples sintered at $1150^{\circ} \mathrm{C}$ at argon atmosphere is shown in Figure 3. The phases formed after the sintering process seem similar among all particle size compositions. Also, intensities of all phases are similar. Therefore, one analysis is given corresponding to all compositions. According to the analysis, all peaks belong to austenite phase, $\mathrm{Cr}_{2} \mathrm{O}_{3}, \mathrm{Cr}_{7} \mathrm{C}_{3}$ and $\mathrm{FeCr}_{2} \mathrm{O}_{4}$ phase of $\mathrm{Ar}$ sintered HF membranes. Since the chromium carbide is formed, it seems that some binders remain in the fiber after the sintering process. Also, there is some amount of $\mathrm{FeCr}_{2} \mathrm{O}_{4}$ phase in the structure which is possibly due to the coagulation process. Moreover, argon atmosphere could play a weak role in preventing oxidation.

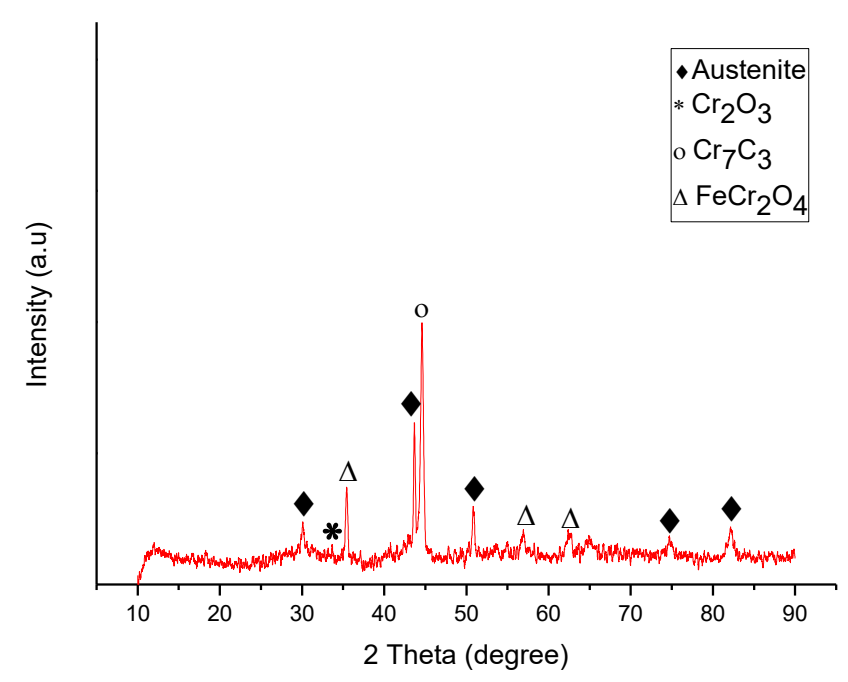

Figure 3. XRD analysis of sintered 316L HF samples. 


\section{B. 3. Electrical Resistivity Analysis}

Electrical resistance of the HF samples are shown in Table 5 with the sample codes. Electrical resistance decreases with decreasing particle size as finest and mixed particle sizes give lower values compared to the coarse one. The finest particle size gives the lowest electrical resistivity value. The lower pore size creates a conductive path and results in denser structure (lower resistance) is obtained.

Table 5. Electrical resistivity values of the sintered HF membranes.

\begin{tabular}{cc}
\hline Sample codes & $\begin{array}{c}\text { Electrical resisvity } \\
(\Omega)\end{array}$ \\
\hline C-SS & $2.85 \pm 0.4$ \\
F-SS & $1.45 \pm 0.5$ \\
M-SS & $1.70 \pm 0.8$ \\
\hline
\end{tabular}

\section{B. 4. Mercury Porosimeter Analysis}

Mercury porosimetry analyzer was used to analyse of the pore size distribution of the sintered samples, and the results are given in Table 6. As the particles sizes are decreased in F-SS and M-SS samples, the amount of porosity decreases from 55 to 44 and $41 \%$ respectively which means samples with finer particles give denser structures with lower porosity. This situation is also seen for the average pore diameter as they are decreased from 4.60 to 1.20 microns. In the study of Allioux et al. [3], it was shown that the pore size is smaller when a multimodal size particles are used. So, the smaller pore size obtained for mixed particle size is similar as it is lower than the finest particle size.

Table 6. Pore analysis of sintered hollow fiber membranes.

\begin{tabular}{ccc}
\hline Sample codes & $\begin{array}{c}\text { Porosity } \\
(\%)\end{array}$ & $\begin{array}{c}\text { Average Pore Diameter } \\
(\mu \mathrm{m})\end{array}$ \\
\hline C-SS & 55.3 & 4.6 \\
F-SS & 44.7 & 1.4 \\
M-SS & 41.2 & 1.2 \\
\hline
\end{tabular}

The pore size distribution of C-SS sample has wide range between 1-30 microns as shown in Figure 4. M-SS has 1-10 microns pore diameter distribution containing high percentage of 1-5 microns. 


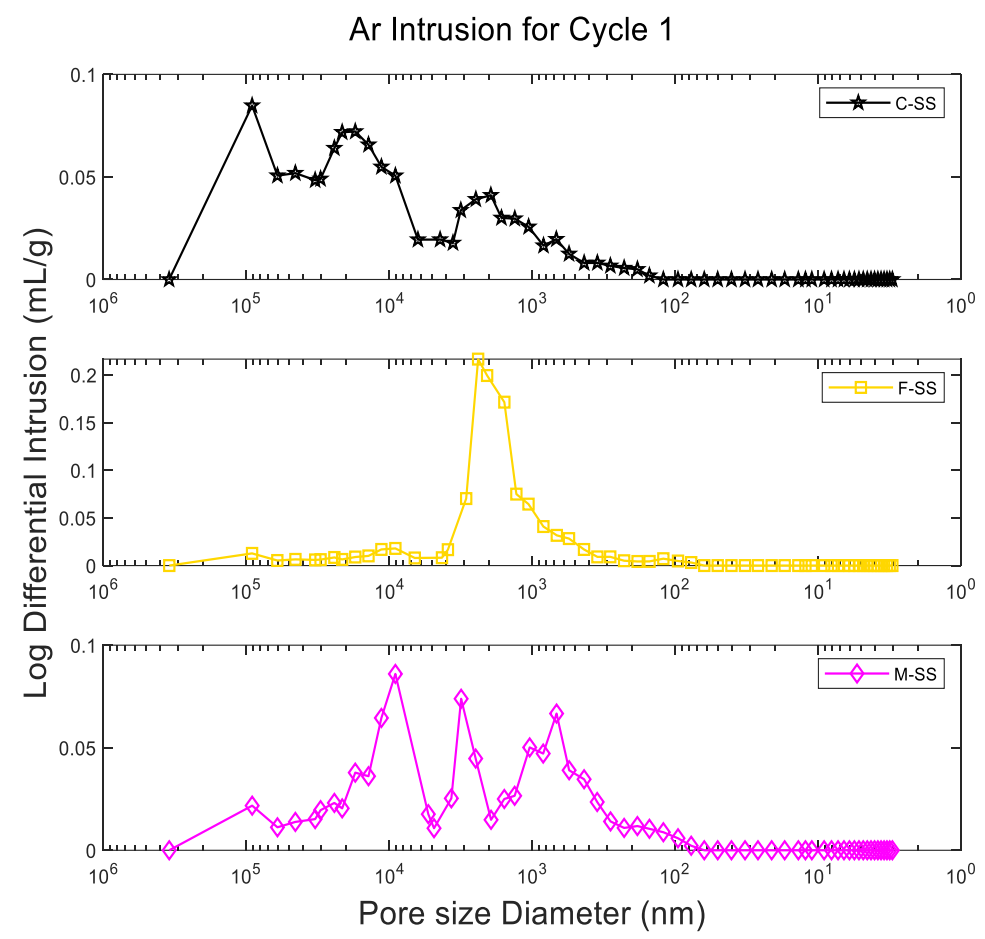

Figure 4. The pore size distribution of Ar sintered $316 \mathrm{~L}$ samples.

\section{B. 5. Bending Tests}

Table 7 shows the bending test results of Ar sintered 316L hollow fiber membranes. HFs with coarse particles (C-SS) have lower bending strength and bending deflection. Finest particle size samples show higher bending strength and bending deflection compared to coarse and mixed particle size samples. Particle size has an impact on mechanical strength. The results of $316 \mathrm{~L} \mathrm{HFs} \mathrm{show} \mathrm{parallel} \mathrm{mechanical}$ properties when compared with the results of study of Wang et al [21], and other studies in the literature $[2,11]$, because the strength increased when the particle size decreased in these studies. For example, our bending strength values are close to the values obtained in the study of Rui et al. [11] as they obtained 228.7 MPa of strength with $70 \%$ solid loading for $316 \mathrm{~L} \mathrm{HFs} \mathrm{by} \mathrm{sintering} \mathrm{at} 1100^{\circ} \mathrm{C}$ under hydrogen atmosphere.

Table 7. Bending test results of sintered 316L hollow fiber membranes.

\begin{tabular}{ccc}
\hline Sample codes & $\begin{array}{c}\text { Bending Strength } \\
(\mathrm{MPa})\end{array}$ & $\begin{array}{c}\text { Bending Deflection } \\
(\mathrm{mm})\end{array}$ \\
\hline C-SS & $26.7 \pm 2.1$ & $1.3 \pm 0.1$ \\
F-SS & $250.2 \pm 25.1$ & $6.1 \pm 1.2$ \\
M-SS & $212.5 \pm 29.9$ & $6.0 \pm 0.6$ \\
\hline
\end{tabular}

SEM images belong to the fracture surfaces of the samples after bending tests are given in Figure 5. In figures $5 \mathrm{a}$ and $\mathrm{b}$, it is clearly seen that there occurred a flat fracture surface with many holes between the particles. Whereas for the F-SS sample, the ductile fracture can be recognized from the deformation as seen in Figure 5c, and micro voids are obviously seen in higher magnifications as in figure 5d. In addition, the structure of the M-SS sample has some micro as well as macro voids leading to the acceptable mechanical properties described earlier (Fig 5e-f). 

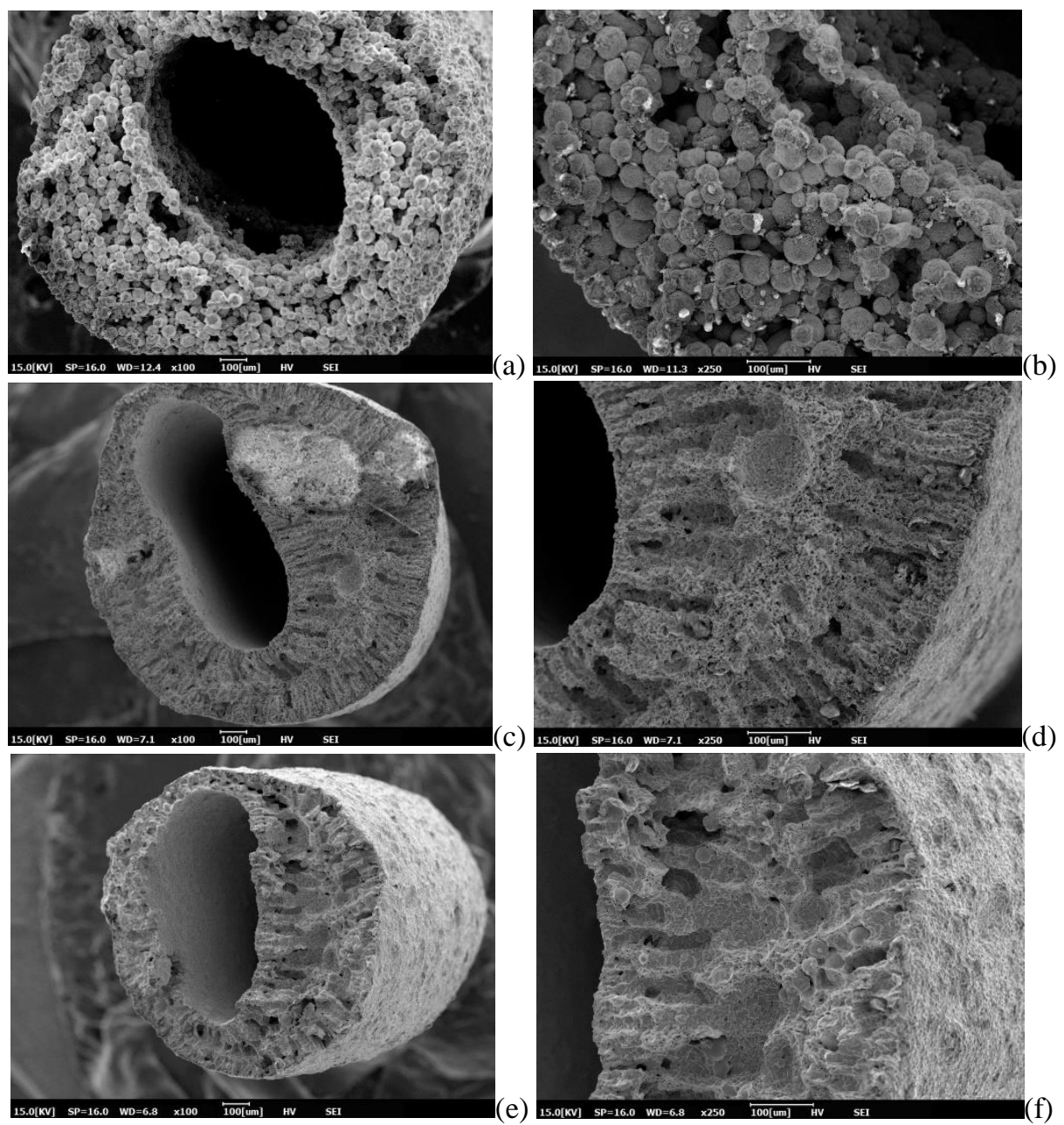

Figure 5. SEM images belong to the fracture surfaces after bending tests $a-b)(C-S S, c-d) F-S S$, e-f) $M-S S$.

Considering the relationship of all these results with each other, it is useful to summarize the effect of particle size on physical properties and thus on mechanical properties. The optimum desired microstructure (finger-like structure in the inner part and sponge-like structure in the outer part) is reached using the finest particle size, however mixed particle size yields a lower amount of porosity in the inner surface but more heterogeneous pore size. Therefore, anyway finest particles yield a higher strength value which is most probably due to the homogenous particle distribution in the outer surface.

\section{CONCLUSIONS}

316L HF samples were produced as both spinning and sintering process was performed successfully. It has been observed that stainless steel HF samples had a homogeneous hollow structure and shape. Following conclusions can be drawn:

1) HF produced from fine particles have higher densification when particle sizes are compared. Also, they have dominant finger-like structure but also some sponge-like structures which are shown in SEM figures. For the samples with coarse particles, large pores are obtained, therefore, finger-like voids and sponge like structures are not obtained. EDS results show that the major components of $\mathrm{HF}$ samples are $\mathrm{Fe}, \mathrm{Cr}, \mathrm{Ni}$, Mo. It seems that all the polymeric binder pyrolysed from HF structure.

2) As a result of $X R D$ analysis of $316 \mathrm{~L} \mathrm{HF}$ membranes, all peaks belong to austenite phase, $\mathrm{Cr}_{7} \mathrm{C}_{3}$, $\mathrm{FeCr}_{2} \mathrm{O}_{4}$, and small amount of $\mathrm{Cr}_{2} \mathrm{O}_{3}$ phase. 
3) The electrical resistance decreases with decreasing particle size as finest and mixed particle sizes (denser structures) give lower values compared to coarse particle size because lower pore size creates a conductive path.

4) As a result of mercury porosimeter analysis, when the particles sizes are decreased, the amount of porosity decreases which means samples with finer particles give denser structures with lower porosity. Although the pore sizes are close to each other for the finest and mixed particle size samples, mixed particle size yields lower porosity than the finest particle size.

5) As a result of bending tests, coarse particle size samples have the lowest bending strength and bending deflection. Also, finest particle size samples show the highest bending strength and bending deflection.

ACKNOWLEDGEMENTS: This study was founded by a Scientific Research Project of İzmir Katip Çelebi University (Project no: 2018-GAP-MÜMF-0003).

\section{REFERENCES}

[1] A. Mustafa, Membran Teknolojileri, $1^{\text {st }}$ ed., Ankara, Türkiye: Türkiye Çevre Koruma Vakfi, 2016, ch. 3, pp.19-39.

[2] D.R. Schmeda-Lopez, S. Smart, E.H.M. Nunes, D. Vasconcelos, W.L. Vasconcelos, M. Bram, W.A. Meulenberg, J.C.D. da Costa, "Stainless steel hollow fibres: Sintering, morphology and mechanical properties," Separation and Purification Technology, vol. 147, pp. 379-387, 2015.

[3] F.-M. Allioux, O. David, M. E. Benavides, L. Kong, D.A.P. Tanaka, L.F. Dumée, "Preparation of Porous Stainless Steel Hollow-Fibers through Multi-Modal Particle Size Sintering towards Pore Engineering," Membranes, vol. 7, no. 40, pp. 1-15, 2017.

[4] B.F.K. Kingsbury, K.Li, “A morphological study of ceramic hollow fibre membranes," $J$. Membr. Sci., vol. 328, pp. 134-140, 2009.

[5] J. Li, L. Wang, Y. Hao, et al., "Preparation and characterization of $\mathrm{Al}_{2} \mathrm{O}_{3}$ hollow fiber membranes," J. Membrane Sci., vol. 256, pp. 1-6, 2005.

[6] X. Tan, S. Liu, K. Li, "Preparation and characterization of inorganic hollow fiber membranes," J. Membrane Sci., vol. 188, 87-95, 2001.

[7] Dumée, L.F., He, L., Wang, Z., Sheath, P., Xiong, J., Feng, C., Tan, M.Y., She, F., Duke, M., Gray, S. "Growth of nano-textured graphene coatings across highly porous stainless steel supports towards corrosion resistant coatings". Carbon, vol. 87, pp. 395-408, 2015.

[8] A. Cassano, N.K. Rastogi, A. Basile, Advances in Membrane Technologies for Water Treatment, $1^{\text {st }}$ ed., Oxford, UK: Woodhead Publishing, 2015, pp. 551-580.

[9] M.W.J. Luiten-Olieman, L. Winnubst, A. Nijmeijer, et al., "Porous stainless steel hollow fiber membranes via dry-wet spinning," J.Membrane Science, vol. 370, pp. 124-130, 2011.

[10] D.R. Schmeda-Lopez, S. Smart, W.A. Meulenberg, J.C. Diniz da Costa, "Mixed matrix carbon stainless steel (MMCSS) hollow fibres for gas separation," Separation and Purification Technology, vol. 174, pp. 150-158, 2017.

[11] W. Rui, C. Zhang, C. Cai, X. Gu, "Effects of sintering atmospheres on properties of stainless steel porous hollow fiber membranes," Journal of Membrane Science, vol. 489, pp. 90-97, 2015. 
[12] B. Michielsen, H.Chen, M.Jacobs, et al., "Preparation of porous stainless steel hollow fibers by robotic fiber deposition," J. Membrane Science, vol. 437, pp. 17-24, 2013.

[13] C. Garcia, F. Martin, P. Tiedra and L. G. Cambronero, "Pitting corrosion behaviour of PM austenitic stainless steels sintered in nitrogen-hydrogen atmosphere," Corrosion Science, vol. 49, pp. 1718-1736, 2007.

[14] P. Samal, J. Pannell, U. Engstrom and O. Mars, "Austenitic stainless steels with enhanced mechanical strength," Proc. in World PM2010 Conference, European Powder Metallurgy Association (EPMA),Florence, Italy, 2010, pp. 1-8.

[15] O. Ertugrul, H.-S. Park, K. Onel and M. Willert-Porada, "Structure and properties of SiC and emery powder reinforced PM 3161 matrix composites produced by microwave and conventional sintering," Powder metallurgy, vol. 58, no.1, pp. 41-50, 2015.

[16] E. Klar, P.K. Samal, Powder metallurgy stainless steels: processing, microstructures, and properties, $1^{\text {st }}$ ed., Materials Park, Ohio, USA: ASM International, 2007, ch. 5, pp.59-68.

[17] S.S.L. Oliveira, S.S.L. Oliveira, R.S.B. Ferreira, H.L.C. Lira, L.N.L. Santana, E.M. Araújo, "Development of hollow fiber membranes with alumina and waste of quartzite," Materials Research, vol. 22, no.1, pp. 1-7, 2019.

[18] T. Kato, K. Kusaka, "On some properties of sintered stainless steels at elevated temperatures," Powder Metallurgy, vol. 27, no. 5, pp. 2-8, 1980.

[19] M.W.J. Luiten-Olieman, L. Winnubst, A. Nijmeijer, M. Wessling, N.E. Benes, "Porous stainless steel hollow fiber membranes via dry-wet spinning," Journal of Membrane Science, vol. 370, pp. 124130, 2011.

[20] S. Lopez, D.R. Smart, E.H.M. Nunes, D. Vasconcelos, W.L. Vasconcelos, M. Bram, W.A. Meulenberg, J.C. Diniz da Costa, "Stainless steel hollow fibres - Sintering, morphology and mechanical properties," Separation and Purification Technology, vol. 147, pp. 381-389, 2015.

[21] Q. Zhong, Z.L. Xu, X. Ma, M. Wang, "Modification of porous stainless steel hollow fibers by adding $\mathrm{TiO}_{2}, \mathrm{ZrO}_{2}$ and $\mathrm{SiO}_{2}$ nano particles”, Journal of Porous Materials, vol. 23, pp. 1529-1536, 2016. 